\title{
Halal Destination Images of Japan: A Visual Content Analysis
}

\author{
VIDI SUKMAYADI \\ RIDWAN EFFENDI \\ Universitas Pendidikan Indonesia
}

\begin{abstract}
The scope of the paper is to investigate the construction of visual communication in shaping a Halal destination image in Japan. Even though Japan is located by a significant distance from Islamic countries, halal tourism prominence has become a rapidly growing interest in the country. In fact, in 2016, Japan won the "World's Best Non-OIC Emerging Halal Destination", and in 2019, the country was ranked in the top three in the category of non-OIC Muslim-friendly destination for Muslim travellers. The paper attempts to describe the exploration of the images found in Japan's tourism promotional brochures. The study aimed at interpreting the denotative and connotative messages of the promotional images in the sampled brochures. A visual content analysis was applied to interpret the brochures' layout and promotional images. The findings of the study imply that distinctive Islamic symbols and Japanese monumental structure are the prominent denotative elements of the brochure. Regarding the connotative elements, the analysis indicates that female Muslim and Halal food become the main Synecdoche in representing Japan's Halal destination image. It is hoped that the study could give new insights for visual communication and tourism practitioners concerning how images can be constructed to represent the audiences' interests and experiences.
\end{abstract}

Keywords: Destination image, halal tourism, Japan, representation, visual analysis.

\section{INTRODUCTION}

The tourism industry has set off to be one of the most significant worldwide economic activities and social interaction. It stimulated people to travel and to consume both services and goods (Salim, 2017). The tourism industry equals the finance, real estate and insurance sectors in financial benefits (Hunter, 2012). Technology and communication cause the emerging development of the tourism industry. Mobility advancement also encourages people to travel, explore, and experience what this vast world has to offer. As a consequence, many countries in the world improve their tourism sites environment and enhances recreational and leisure opportunities to cater to both tourists and residents' interest.

Among many tourists' interests, there has been a growing expansion in the outbound and intra-regional tourism movements in the Islamic world. The rapid mobility of Muslimbased tourists has created a subcategory in the tourism industry known as halal tourism. The term halal tourism can be put in a nutshell as an object and or action which is permissible to use or engage in the tourism industry, according to Islamic values (Battour \& Ismail, 2016). Halal tourism is a distinct subset of the tourism industry for Muslim travellers, where the services refer to the Islamic Sharia teachings (Rasul, 2019). In other words, Halal tourism can also be understood as the type of tourism that adheres to the teachings of Islam. The tourism industry is heavily dependent on visitors' experiences, especially to customer service and delight. In recent years, an increasing growth trend in numbers of international movements has been witnessed in the Halal tourism market in the world. Dinar Standard (2012) reported that Halal tourism was worth US\$ 137 billion in 2013 and expected to reach US\$ 181 billion by the end of 2018. In exploring the vast potential of Halal tourism, tourism providers in many 
countries start to adapt themselves to cater to the needs of Muslim tourists by improving their halal services and infrastructure.

One country that particularly seizes the opportunity of Halal tourism in Japan. In 2004, there were only around 30.000 Muslim tourists visited the country. In only a decade, the number has increased sharply to more than 700.000 Muslim tourists in 2017 (Wira, 2017). Moreover, it is estimated that Japan would welcome more than one million Muslim visitors in 2019. To show how serious the country in implementing halal policies in the tourism sector, the Japanese government has been applying a free-visa policy for Muslim-majority countries in Southeast Asia and they have been increasing the number of halal restaurants and prayer rooms since 2014. It is not surprising that in 2016 Japan was awarded the "World's Best NonOIC Emerging Halal Destination" with Tokyo that was considered as the best-prepared destination in the country for accommodating Muslim travellers, followed by Osaka and Hokkaido.

To support and develop the halal tourism service, the Japanese government and local tourism providers attempt to portray their tourist destinations favourably by providing valuable information and establishing the destinations' image in the form of visual promotion tools such as posters and brochures. In the current emergence of the digital world, is it still essential to have such visual tools as a brochure to promote a product? The answer is affirmative because along with the advertising, website, social networking, and other marketing efforts, a business brochure serves as an integral part of any product or service branding process. As stated by Hunter (2012), visual promotion tools have a significant impact on introducing and describing a particular destination and its services. He also pointed out the importance of having the right composition of a brochure as a visual promotion tool; " $\mathrm{A}$ badly designed brochure can say as much about your whole business as a well-designed one can so be sure that the visual promotion tool sends out the precise message that the sender wants"(Hunter, 2012).

Furthermore, the use of language and visual elements in the visual promotion tools are also contributing as fundamental factors that create particular discourses about the image and identity of particular destinations (Adams, 2004; Salim, 2017; Stepchenkova \& Zhan, 2013). As a matter of fact, since the 1970s, the study of destination image and its relations to travel pattern and tourism industry has been carried out (Mayo, 1973; Hunt, 1975) and comprises many related studies up to the present time.

Earlier studies in the 2000s were focused mostly on meta-reviews of the destination image. Pike (2002) reviewed 142 destination image academic articles that were published in the literature from 1973 to 2000 to provide a reference guide for destination image researchers in studying and analysing the trends of the method, focus, and context of destination image studies.

Additionally, other researchers had set their attention on exploring meta-analysis of destination image by using structured surveys of human respondents (Garrod \& Kosowska, 2012; MacKay \& Couldwell, 2004; Stepchenkova \& Zhan, 2013; Tasci, Gartner, \& Tamer Cavusgil, 2007). In recent years, destination image studies have expanded by focusing on textual data from printed images and or online sources (Hao, Wu, Morrison, \& Wang, 2016; Önder \& Marchiori, 2017; Salim, 2017). However, fewer studies have addressed visual representations of destination images, particularly in how language usage and visual element can serve a significant role in representing the destination as the tourism promotion modes. 
As a further exploration of the previous studies, this study focuses on analysing and identifying the visual representative of Muslim and Halal tourism through textual and visual elements in tourism brochures designed by the Japanese tourism stakeholders. Furthermore, this paper aims to interpret the noticeable (denotative) and implied (Connotative) messages being communicated in the promotional images of Japan's Halal tourism.

\section{Visual Destination Image as Text}

\section{LITERATURE REVIEW}

In this paper, the authors focused on the analysis of Japanese Halal destination images portrayed on the promotional brochures. The tourism industry has an ambivalent relationship with visual imagery. By having an appropriate choice of visual imagery, a visual promotional tool can convey a clear identity and sense of place which is embodied in a destination's physical form, history and social activity (Human, 1999).

The visual images and the language features on the brochures play an essential role as the representation and of the destination's reality. Projected images spark the interest of potential tourists and able to shape or even reinforce the existing images that result from previously acquired information from various sources, thus affecting tourists' perceptions of the tourist destinations (Stepchenkova \& Zhan, 2013). Destination promotion texts systematically use images to make 'visible' the absent and intangible object of promotion ( $P$. M. Burns, Lester, \& Bibbings, 2010). The text (both visual and language features) on the brochures provide a frame of understanding and assuming certain products and destinations. In other words, tourism brochures are an ideal text for discovering the language and visual image offered to potential tourists.

These texts evolve into tempting images when the tourist begins to actively pursue information about a tourist site from brochures, guidebooks, online sources and many more. It can be said that the images are synchronised into a perceived image of front-row seat travel (Salim, 2017). Destination image theory has been identified as the generic term for complex relationships between imagery, projected destination image and perceived destination image (Garrod \& Kosowska, 2012).

Those three interconnected elements can be separately described as follows; (1) destination imagery is an objective representation of a site that focuses on a largely idealised topography of the touristic landscape, its material objects and experiences (Wolcott, 1990); (2) perceived destination image is defined as the intentional or incidental exposure to the projected destination image and its consequences on the readers both individually or collectively audiences (Garrod \& Kosowska, 2012); and (3) projected destination image is the process of generating and packaging of creative imagery in printed or electronic forms for the sake of reviewing, promoting or marketing purposes (Pritchard \& Morgan, 2001).

As added by Hunter (2012), Destination imagery consists of the landscape characteristics as an output of the actual imagined or perceived exposure of the tourist to the destination or its representations. Accordingly, the origin of the destination imagery emerges from the features of the destination as they appear to those who experience it personally or through other people's feelings and descriptions.

In this case, projected images are visual portraits designed and framed by tourism providers to stimulate and emphasise the product or destination that they would like to promote. While the perceived image is the subjective interpretation of an image from the perspective of tourists, Baloglu and McCleary (1999) stated that perceived image is an 
important indicator of destination value and the visitors' satisfaction, and for this reason, shaping the visitors' potential travel intention, travel behaviour, and patterns of consumption. As a text, a projected image in a brochure is informative but principally it is promotional because a brochure is intended to create a positive image of the destination and to turn readers into visitors (Francesconi, 2011).

Furthermore, destination imagery consists of features of the landscape as generated via the tourists' imagined, real, or perceived relation to the destination or its representations (Hao et al., 2016; Hunter, 2012). Destination imagery consists of denotative and connotative messages, and it originates in the features of the promoted destination as they appear to those who experience it directly or through the feelings or actions of other visitors who already visited the destination. Halal tourism, as a form of promotion, is channelled through destination imagery to generate an ideal text that can represent the Halal concept. In Japan, the projected image of Halal is a promotional product that showcases the openness of the country towards the value of Islamic teachings and its Halal concept. The projected image attempts to encourage Muslims visitors to seek culturally immersive travel experiences outside of the traditional Halal tourism destinations such as the United Arab Emirates, Indonesia, and Malaysia (Kamin, 2019). In disseminating the projected image, the Japanese government and tour operators produced tourism brochures than can be found and accessed by international visitors at Japanese airports, tourism information centres and online.

\section{Visual Analysis Method}

Each visual imagery design is created by communicating the messages. Visual artwork consists of three aspects; image, publisher and audience aspect (Adams, 2004). In this paper, the authors focused on the image aspect to identify and analyse the denotative and connotative message describe the visual communication aspect of promotional brochures.

Destination imagery, whether perceived or projected image, communicates descriptions that shape or reinforce travellers' perceptions of the destination. There are two primary components of a visual image; photo composition and content (Albers \& James, 1988). Photo Composition is how visual images are linked to each other and showed to viewers. Content refers to the appearances or signs captured in a photo in their totality. Aside from the components, destination images are designed to construct meaning. The meaning of an image as a text can be constructed from two perspectives, metonymic or metaphoric. From the metonymic perspective, all signs presented on a photograph stand for themselves and are interpreted at face value (Garrod \& Kosowska, 2012). This metonymic perspective can be illustrated in photos of beautiful beaches to represent a tropical archipelagic destination where beaches are a well-known characteristic in portraying an archipelago. The metaphoric perspective, in contrast, is concerned with what the image signifies beyond mere appearances (Stepchenkova \& Zhan, 2013). All elements of a photograph are treated as text that refers collectively to a particular meaning that lies beyond the skin of a picture.

Visual methods are employed as an attempt to create an understanding of visual representation through photos or images that appear in media. Crouch and Lübbren (2003) added that visual methods use specific video and photography analysis techniques to collect primary data, including content analysis. The study method used in this paper is shaped by previous studies on visual culture and tourism, particularly in the analysis of tourism projected images both in printed or online media (Garrod \& Kosowska, 2012; Hunter, 2012; Salim, 2017; Stepchenkova \& Zhan, 2013; Tasci et al., 2007) that focused on the analysis of photographic elements of images utilised for tourism promotion media. While in the current study, the 
authors used the visual content analysis approach based on a synthesis of visual research techniques (Hunter, 2012; Van Leeuwen \& Jewitt, 2004). The analysis in this paper covers both denotative and connotative message appeared on the promotional brochure and emphasised on how the Halal concept is pictured on that particular promotional media.

\section{Halal Tourism in Japan}

The fast-growing Halal tourism industry has caught the attention of the Japanese government. The government is aware that the tourism industry heavily depends on visitors' needs and in recent years, a high number of visitors from Islamic countries is growing rapidly (Wira, 2017). The growth of Islamic tourism offers an opportunity for potentially higherincome markets. As a response to the situation, the Japanese government, with its local tourism operators, have been endorsing new policies to cater to the needs of Muslim visitors and to be more congruent with the Halal values. Public Policies, facilities, culinary products, and consumer protection have been adjusted to support the Halal tourism industry in the country.

A massive influx of Muslim travellers has triggered a boom in Japan's halal restaurants and sharia-based hotels. As reported by Hamid (2018) in catering Muslim visitors' needs, Japanese tourism providers have set up sharia-based supporting facilities such as hotels, including one at the globally known Mount Fuji and they have also build prayer rooms at International airports in Japan as well as offering a halal culinary experience for Muslims, and continuing the plan to make Japanese public areas more Muslim friendly in the years ahead.

Moreover, the Japanese government has endorsed Halal certification bodies to assist both the Islamic community and visitors. The Halal certification body is divided into three categories: non-profit organisations, religious enterprises, and independent organisational forms (Adidaya, 2016). The certification for halal food in Japan was first established in 1986, managed by the Japanese Muslim Association (JMA). However, since this organisation was essentially a voluntary religious organisation, the JMA at the time was not focused on halal certification for business purposes. As an effort to adapt with the tourism business the government invited the Malaysian Halal Corporation (MHC) to establish its branch office in Japan and become the organisations that issue halal certification for business-based enterprises in Japan (Kawabata, 2015). Afterwards, the Japanese tourism sector is currently riding on the booming of the global Muslim travel market, which has seen a massive change in the past two decades.

The rigorous effort of the Japanese government and its tourism operators have resulted in a positive review throughout the world. By 2016 Japan won the "World's Best NonOIC Emerging Halal Destination" with Tokyo that was considered as the best-prepared destination in the country for accommodating Muslim travellers, followed by Osaka and Hokkaido

\section{METHODOLOGY}

The study is qualitative, and the authors have employed a visual content analysis method in collecting and analysing the data. The purposive sample in this paper consists of $50 \mathrm{Halal}$ tourism digital brochures in Japan, which available online within the year of 2018 and 2019.

In analysing the data, the authors used the analytical framework developed by Leuween, Jewitt (2004) and Hunter (2012). Based on the visual analysis foundation, the authors performed five coding stages. First, collecting visual data from Japanese tourism 
providers; secondly, sorting visual data to identify the brochures' type and structure, and the third step is generating categories based on the dominant denotative elements. The next step is identifying studying the frequency and type of denotative element found in both visual and written features of the brochure. Finally, the authors analyse connotative elements implied by the composition of images on the promotional media.

In the visual content analysis, coding becomes the most crucial step in analysing the data. With visual objects, coding means attaching a set of descriptive labels or categories to the photos and language features (Hao et al., 2016). The coding categories are observable in sample pictures and clearly describe what composition is in the image. The coding itself relies on a posited connection between the visual contents and the broader cultural context. Furthermore, the coding categories have some characteristics regardless of their assumed status as interpretive or descriptive (Rose, 2001). The coding categories were based on image composition and cultural expression in related to the study aim and question. In a slightly simpler way, the research methodology is described in the following table.

Table 1: Research Methodology

\begin{tabular}{|c|c|c|c|}
\hline Research Questions & Visual Data & Data collection & Analysis method \\
\hline $\begin{array}{l}\text { What denotative elements } \\
\text { featured in the Japanese Halal } \\
\text { Tourism Brochures? }\end{array}$ & $\begin{array}{l}50 \text { Halal Tourism } \\
\text { digital brochures } \\
\text { of Japan available } \\
\text { online }\end{array}$ & $\begin{array}{l}\text { Textual coding } \\
\text { and categorising } \\
\text { from the } \\
\text { brochures }\end{array}$ & $\begin{array}{l}\text { Visual Content Analysis adapted from } \\
\text { Leuween and Jewitt (2004) and } \\
\text { Hunter (2012) analysis model. } \\
\text { The visual data are collected, } \\
\text { categorised, interpreted and } \\
\text { described in descriptive narrative } \\
\text { form. }\end{array}$ \\
\hline
\end{tabular}

\section{RESULTS AND DISCUSSION}

\section{Denotative Elements of Japanese Halal Tourism Brochure}

Denotative elements of the visual elements are analogical to reality and interpreted. They are coded according to their composition and importance within the images (Hunter, 2012). At this point, the visual content analysis is aimed at identifying the denotative representations of Halal concepts as they appear in the Japanese Halal tourism brochures. In the visual content analysis, denotative elements of photographs are used to identify the visual image types and frequency. Furthermore, the findings of the analysis are described in the following table.

Table 2: Denotative Elements

\begin{tabular}{|c|c|c|}
\hline Visual Category & Image Representatives & Frequency \\
\hline \multirow[t]{4}{*}{ Brochure Headlines } & Stating "Muslim" in the headline & 31 \\
\hline & Stating "Halal" in the headline & 12 \\
\hline & Halal Logo ( in front page) & 5 \\
\hline & $\begin{array}{l}\text { Other Headlines (Stating Only Japanese tourist districts and } \\
\text { landmarks) }\end{array}$ & 2 \\
\hline \multirow[t]{2}{*}{ Brochure Language } & English & 40 \\
\hline & English and Japanese & 10 \\
\hline Brochure' Dominant & White & 22 \\
\hline \multirow[t]{2}{*}{ Combinations } & Green & 12 \\
\hline & Other colour combinations & 16 \\
\hline \multirow[t]{3}{*}{ Religious Symbols } & Women in Hijab (wearing veil) & 30 \\
\hline & Place of Worship (Masjid/Musalla) & 16 \\
\hline & Halal logo/code in Arabic & 12 \\
\hline
\end{tabular}




\begin{tabular}{lll}
\hline Visual Category & Image Representatives & Frequency \\
\hline Halal Food and Beverages & Beef & 27 \\
& Noodles & 23 \\
& Chicken & 21 \\
& Vegetables & 20 \\
& Seafood & 17 \\
& Rice & 7 \\
Tourism Landmarks & Green Tea (Ocha) & 2 \\
& Cityscapes and Monumental structures & 50 \\
& Restaurants & 24 \\
Other Images & Festival, event, and Performances & 7 \\
& Accommodation & 7 \\
& Maps & 19 \\
\hline
\end{tabular}

In term of Photographic data, the most frequent representation of Halal was women in Hijab, with 30 photographs or $60 \%$ of the total sample brochures. As a Brochure headline, the word "Muslim" became the most frequent language representative of Halal tourism (31 images). Another visual representation of Halal tourism found in the brochure was food. Beef (27) and Noodles (23) highlighted the representative of Halal food in the Japanese Halal tourism brochures. In addition to Halal image representation, Islamic place of worship or Masjid images were found. 32\% of total brochures placed Masjid as part of the Halal representation.

The projected images indicated that Japan has started building praying facilities for Muslim visitors. In line with the growth of Muslims' praying facilities, Yildirim (2015), reported that in the 1970s, only two masjids existed in the country. More recently, there are about 200 masjids and small praying rooms (Mushala) across Japan, and it shows how the country tries to embrace and cater to the growing market of Muslim travellers. Destination image is acknowledged as one of the primary factors for tourists in deciding on their destination choice (Önder \& Marchiori, 2017). In line with the statement, the choice of masjids as one of the projected destination images to represent a Muslim friendly destination is considered as a beneficial strategy to withdraw more Muslim travellers' attention. The message within the image of masjids seems to ensure that Muslim visitors are almost instinctively conveyed to a destination that mainly intended for Muslim tourists to visit.

As for the tourism landmarks, cityscapes and monumental structures were the denotative elements most frequently appearing in the brochure images. All of the brochures had cityscapes and monumental structures such as Mount Fuji, Tokyo tower, Japanese Castles and other iconic structures that related to cities which were promoted in the brochures. Moreover, the Japanese tourism operators have added maps (19), digital barcode (15), and mobile application to strengthen the information value of the brochure. The digital support in the brochures can impose a new way of presenting services and products to the potential audience. The digital support on a promotional tool offers endless customisation, ease of creation and portability, which make lives easier for both of the content providers and potential customers (Kunjal, 2017).

The representation of cityscapes and monumental structures do not appear directly related to Islamic values. Festivals, events, and performances (seven images) are also difficult to connect to the Halal representation. They seem indicative of general tourism promotion. However, Islamic values and Japanese culture in the brochure headline can serve as a 
message emphasis and stimulus to the readers (Edlund \& Nilsson, 2006). Also, the projected destination image plays the role of a commercial product and works to influence visitors' personal travel goals and choices (Hunter, 2012). Thus, the photo compositions in the brochure headline indicated that potential Muslim visitors should be worry-free in visiting the country since both Halal concept and the culture of Japan could seem to go hand in hand.

\section{Halal Synecdoche and its Connotations}

Generally, synecdoche can be described as a figure of speech in which a part is made to represent the whole or vice versa. In the field of tourism, the synecdoche is a re-imaging instrument for containing the complex reality of a broad theme by making a projected destination image focus on one or more highly visual elements to represent the theme (Hunter, 2012). The synecdoche carries both connotative and denotative messages concerning the overview concept of a theme. To illustrate the concept of synecdoche, the authors would like to take Indonesia as an example. Although there are more than 17.000 islands in Indonesia, the Island of Bali became the primary tourist reference when talking about Indonesian tourism. As a consequence, Bali becomes the synecdoche and the most frequent image pictured in Indonesian tourism promotional media. In this study, the synecdoche in the brochures attempts to represent Halal as a whole in the best possible and most straightforward way, mainly to influence the perception of targeted external readers.

Based on the study findings, two of the most synecdochical feature of Japan's Halal destination image found in brochures were female Muslims and culinary-related images. The image of Muslim female wearing hijab pictured in $60 \%$ of the brochures and all of the picture was placed in the brochure headline. Moreover, the distinctive image of women in hijab even able to replace the dominant Japanese events and cultural performance images that usually found in a regular Japanese tourism brochure.

The female Muslim images connote a whole unitary representative of Halal tourism in the brochure. Parallel to the female Muslim connotation, women have been known as cultural bearers. Their role has been both symbolic, to represent the nation or culture, and functional, to transmit it (Winter, 2016). The women as a projected image borne the message of Islamic cultural representation through identification concerning their distinct appearance (wearing hijab). By portraying hijab-wearing females as the cultural representation, the brochures have generated a brand identity to attract potentially relevant customers. The portrayal on the brochures is in line with the notion that a destination image includes intentional marketing efforts as well as sources not directly associated with the destination (Hunt, 1975), and consumers generate product relationships based on their symbolic attributes, a distinctive brand identity may help create a set of specific and also beneficial product memory associations among the consumers (Kok \& Shuhaida, 2015; Salim, 2017). Hence, potential audiences will quickly identify that the brochure is promoting something that related to the Halal concept whenever they see Islamic symbols projected in the brochure.

The second Synecdoche of Halal representative is food images. As mentioned previously, The projected destination image serves as a promotional and commercial product that obliterates alternative perceptions (Hunter, 2012; Mackay \& Couldwell, 2004; Pike, 2002). Generally, the synecdoche image operates to influence tourists' choices. Food, in this case, becomes the synecdoche of Halal tourism because it is what comes first to most Muslim visitors when they seek Halal tourism. In relating to this fact, one of the world's leading authority on Halal travel; Crescent rating (2018) identified that food becomes the most required needs among other six basic needs of Muslim travellers. The data indicate that in 
the perspective of Muslim travellers, Halal is significantly associated with food and becoming their main concern whenever and wherever they travel.

For that reason, Halal food became one of the main features of the brochure to represent the Halal concept and to promote the culinary treasure of the destination. The two synecdoche images also imply to persuade potential Muslim visitor that Japan is a Muslim friendly country. The notion is in line with Kamin (2019) and Ryan (2015) who reported that the goal of embracing and providing the concept of halal tourism is not just to make it easier for Muslim travellers to find prayer spaces, alcohol-free activities, and halal food that appeal to them. It is also to support Muslim travellers all across the globe to come out of their comfort zones and feel empowered by exploring the world. Finally, to sum up, the Halal synecdoche of the brochures, the authors have listed the Japan Halal tourism synecdochical features and the denotative and connotative elements of the images in Table 3.

Table 3: Summary of Japanese Halal Tourism Brochures Visual Content Analysis

\begin{tabular}{|c|c|c|}
\hline Halal Synecdoche & Denotative Elements & Connotative Elements \\
\hline \multirow[t]{2}{*}{ Female Muslim } & Wearing veil (Hijab) & $\begin{array}{l}\text { Non-ordinary aspects of a unitary } \\
\text { whole }\end{array}$ \\
\hline & $\begin{array}{l}\text { Mingling with Japanese people } \\
\text { Having joyful expression }\end{array}$ & $\begin{array}{l}\text { Women as cultural markers and } \\
\text { bearers }\end{array}$ \\
\hline \multirow[t]{3}{*}{ Food (Halal) } & Beef, noodles, and vegetables & $\begin{array}{l}\text { Distinctive image of Halal } \\
\text { representation }\end{array}$ \\
\hline & Other non-pork food & Representing Muslim visitors needs \\
\hline & No alcohol beverages & Promoting tourism product \\
\hline
\end{tabular}

\section{CONCLUSION}

This paper describes an interpretation of projected Halal destination image in the form of Brochure as a tourism promotional media. The brochures aim to persuade people into consuming the tourism products and services being promoted. For that reason, the image composition and diction used in the brochures should be carefully designed to gain significant attention and able to influence personal travel objectives of the potential visitors.

The projected destination image was analysed using visual content analysis methods to interpret pictures and headlines published in Japanese Halal tourism digital brochures. The findings found that the Halal image representation in Japan focused on displaying Female Muslims wearing Hijab, Japanese Culinary suitable for Muslim, and Japanese iconic tourism structures. Those images suggest a unitary whole on the concept of Halal tourism in Japan.

For further developments, the study did not measure the effectiveness of the brochures toward their audience quantitatively. Thus, the authors would like to recommend other subsequent studies to quantitatively investigate the effectiveness of the visual promotion tools design toward the audience attention or perception. It is expected that by having the results both qualitatively and quantitatively, the study can provide more insights into the visual communication study and the tourism communication study as a whole.

Lastly, by amplifying the Halal synecdochical images and combining with the hybrid culture of Japan, the brochures suggest that although the country is not a conventional Muslim tourism destination, Japan is now thriving to be a Muslim-friendly destination. Moreover, the images also attempt to encourage visitors in how they should experience both tourism pleasure and the pleasure to practice their faith. 


\section{BIODATA}

Vidi Sukmayadi is a lecturer of Communications at Universitas Pendidikan Indonesia, and he is currently taking his graduate studies at the Faculty of Communication and Media Studies, Universiti Teknologi Mara, Malaysia. Email: vsukmayadi@upi.edu

Ridwan Effendi is an associate professor of communications at Universitas Pendidikan Indonesia. Email: reffendi09@upi.edu 


\section{REFERENCES}

Adams, K. M. (2004). The genesis of touristic imagery politics and poetics in the creation of a remote Indonesian island destination. Tourist Studies, 4(2), 115-135. https://doi.org/10.1177/1468797604054378

Adidaya, Y. A. (2016). Halal in Japan: History, issues and problems. Norway: The University of Oslo.

Albers, P. C., \& James, W. R. (1988). Travel photography. Annals of Tourism Research, 15(1), 134-158. https://doi.org/10.1016/0160-7383(88)90076-X

Baloglu, S., \& McCleary, K. W. (1999). A model of destination image formation. Annals of Tourism Research, 26(4), 868-897. https://doi.org/10.1016/S0160-7383(99)00030-4

Battour, M., \& Ismail, M. N. (2016). Halal tourism: Concepts, practises, challenges and future. Tourism Management Perspectives, 19(Part B; July 2016), 150-154. https://doi.org/10.1016/j.tmp.2015.12.008

Burns, P. M., Lester, J. A., \& Bibbings, L. (2010). Tourism and visual culture - Volume 2: Methods and case. Wallingford: CABI. https://doi.org/10.1079/9781845936112.0000

Crouch, D., \& Lübbren, N. (2003). Visual culture and tourism (1st ed). Oxford: Berg Publishers. ISBN: 9781859735886

Dinar Standard. (2012). Global Muslim lifestyle travel market landscape and consumer needs study-executive summary. Retrieved on February 22, 2018, from http://advisory.dinarstandard.com/travelstudy/\#top

Edlund, M., \& Nilsson, H. (2006). The use of print ads for an international brand. Sweden: The Luleå University of Technology.

Francesconi, S. (2011). Images and writing in tourist brochures. Journal of Tourism and Cultural Change, 9(4), 341-356. https://doi.org/10.1080/14766825.2011.634914

Garrod, B., \& Kosowska, A. (2012). Destination image consistency and dissonance: A content analysis of Goa's destination image in brochures and guidebooks. Tourism Analysis, 17(2), 167-180. https://doi.org/10.3727/108354212X13388995267823

Hamid, A. J. (2018, December 30). Japan is making a mark in Muslim tourist market. NST. Retrieved from https://www.nst.com.my/news/nation/2018/12/445276/japanmaking-mark-muslim-tourist-market

Hao, X., Wu, B., Morrison, A. M., \& Wang, F. (2016). Worth thousands of words? Visual content analysis and photo interpretation of an outdoor tourism spectacular performance in Yangshuo-Guilin, China. Anatolia, 27(2), 201-213. https://doi.org/10.1080/13032917.2015.1082921

Human, B. (1999). Kodachrome icons: Photography, place and the theft of identity. International Journal of Contemporary Hospitality Management, 11(2/3), 80-84. https://doi.org/10.1108/09596119910250733

Hunt, J. D. (1975). Image as a factor in tourism development. Journal of Travel Research, 13(3), 1-7. https://doi.org/10.1177/004728757501300301

Hunter, W. C. (2012). Projected destination image: A visual analysis of Seoul. Tourism Geographies: An International Journal of Tourism Space, Place and Environment, 143, 419-443. https://doi.org/10.1080/14616688.2011.613407

Kamin, D. (2019, January 18). The rise of halal tourism. The New York Times. Retrieved from https://www.nytimes.com/2019/01/18/travel/the-rise-of-halal-tourism.html

Kawabata, T. (2015). "Harāru bijinesuno" būmuka to kadai: Masumedia no ronchō kara yomitoku. Chūtō Kenkyū, 523, 62-74. 
Kok Shiong Pong \& Shuhaida Md Noor. (2015). The influence of destination personality on brand image evaluation among archaeological tourists. Jurnal Komunikasi: Malaysian Journal of Communication, 31(1), 133-152. https://doi.org/10.17576/JKMJC-20153101-07

Kunjal, P. (2017). 8 key benefits of digital brochures for online business promotion. Socialnomics. Retrieved on December 28, 2019, from https://socialnomics.net/2017/04/25/8-key-benefits-of-digital-brochures-for-onlinebusiness-promotion/

MacKay, K. J., \& Couldwell, C. M. (2004). Using visitor-employed photography to investigate destination image. Journal of Travel Research, 42(4), 390-396. https://doi.org/10.1177/0047287504263035

Mayo, E. J. (1973). Regional images and regional travel behaviour. Research for changing travel patterns: Interpretation and utilisation. Paper presented at Travel Research Association 4th Annual Conference, Sun Valley, Idaho.

Önder, I., \& Marchiori, E. (2017). A comparison of pre-visit beliefs and projected visual images of destinations. Tourism Management Perspectives, 21, 42-53. https://doi.org/10.1016/j.tmp.2016.11.003

Pike, S. (2002). Destination image analysis - A review of 142 papers from 1973 to 2000. Tourism Management, 23(5), 541-549. https://doi.org/10.1016/S02615177(02)00005-5

Pritchard, A., \& Morgan, N. J. (2001). Culture, identity and tourism representation: Marketing Cymru or Wales? Tourism Management, 22(2), 167-179. https://doi.org/10.1016/S0261-5177(00)00047-9

Rasul, T. (2019). The trends, opportunities and challenges of halal tourism: A systematic literature review. Tourism Recreation Research, 44(4), 434-450.

Rose, G. (2001). Visual methodologies: An introduction to the interpretation of visual materials. Thousand Oaks, UK: Sage.

Ryan, C. (2016). Halal tourism. Tourism Management Perspectives, 19, 121-123. https://doi.org/10.1016/j.tmp.2015.12.014

Salim, M. A. M. (2017). Enhancing destination image on tourism brochure of Barru Regency Sulawesi Selatan, Indonesia: A tourism discourse perspective. Tourism, 65(2), 247257. Retrieved from https://hrcak.srce.hr/183656

Stepchenkova, S., \& Zhan, F. (2013). Visual destination images of Peru: Comparative content analysis of DMO and user-generated photography. Tourism Management, 36, 590601. https://doi.org/10.1016/j.tourman.2012.08.006

Tasci, A. D. A., Gartner, W. C., \& Tamer Cavusgil, S. (2007). Conceptualization and operationalization of destination image. Journal of Hospitality \& Tourism Research, 31(2), 194-223. https://doi.org/10.1177/1096348006297290

Van Leeuwen, T., \& Jewitt, C. (2004). The handbook of visual analysis. Thousand Oaks, UK: Sage. https://doi.org/10.4135/9780857020062

Winter, B. (2016). Women as cultural markers/bearers. In, The Wiley Blackwell Encyclopedia of Gender and Sexuality Studies. Hoboken, NJ: John Wiley \& Sons. https://doi.org/10.1002/9781118663219.wbegss695

Wira, N. N. (2017, December 8). Japan to become more popular in 2018: Muslim travel index. The Jakarta Post. Retrieved from http://www.thejakartapost.com/travel/2017/12/08/japan-to-become-morepopular-in-2018-muslim-travel-index.html 
Wolcott, H. (1990). Making a study "more ethnographic." Journal of Contemporary Ethnography, 19(1), 44-72. https://doi.org/10.1177/089124190019001003

Yildirim, C. (2015, May 31). Muslim population in Japan increases with Islamic demands. Daily Sabah. Retrieved from https://www.dailysabah.com/asia/2015/05/31/muslimpopulation-in-japan-increases-with-islamic-demands 